\title{
Navigating the Future Husband: Perempuan Muda, Negosiasi Pernikahan dan Perubahan Sosial
}

\author{
Rani Dwi Putri, Prasakti Ramadhana Fahadi, Amelinda Pandu Kusumaningtyas, \\ Ariane Utomo, Oki Rahadianto Sutopo \\ Youth Studies Centre Fisipol UGM | University of Melbourne \\ ranidwiputri@ugm.ac.id | prasakti.r.f@ugm.ac.id | amelinda.pandu.k@mail.ugm.ac.id | \\ ariane.utomo@unimelb.edu.au | oki.rahadianto@ugm.ac.id
}

\begin{abstract}
Economic development and social-political change in Indonesia have been accompanied by wider education access especially for women. These have resulted in a number of profound inter-generational shifts in the process of transition to work and marriage - one of them is a trend toward self-choice marriage. This study uses qualitative methods in particular in-depth interviews and focus group discussion as data collection techniques. By combining two theoretical lenses of generation change and post-feminism, this article explores the practice and meaning of choices in the quest for an ideal husband, through exploring the subjective narrative of four young women. All informants have their own point of views about the ideal partner criteria, thus representing uniqueness and diversity of contemporary generation. Terms such as pious, responsible and economically-established are still considered important in their imagination, however, the most essential for an ideal partner is a prospective man who can negotiate between work role, family and tradition in the context of late modernity. It can be argued that those views are frequently influenced by existing normative values of family and neighbourhood showing that 'feminist consciousness' is still a privilege.
\end{abstract}

KEYWORDS: Ideal Husband | Young Women | Generation Change | Post-Feminism

\section{PENDAHULUAN}

Runtuhnya rezim Orde Baru dan lahirnya era Reformasi pada tahun 1998, telah membawa pada periode yang lebih demokratis terutama menyangkut pergeseran norma-norma mengenai peran gender, pernikahan dan keluarga (Afrianty 2020; Khoiron dan Eliyanah 2020; Utomo dan Sutopo 2020; Smith-Hefner 2019; Utomo 2014). Di satu sisi, semakin luasnya kesempatan dan akses sekolah dan pekerjaan serta kebutuhan mobilitas sosial yang meningkat ditambah dengan maraknya penggunaan teknologi IC'T membawa generasi muda pada potensial partner dalam marriage market yang lebih beragam dan kompleks (Nilan 2008; Smith-Heffner 2005, 2019; Utomo et al 2016; Kusumaningtyas dan Hakim 2019). Badan Statistik Indonesia (2019) menunjukkan bahwa perempuan muda (usia 16-30 tahun) dengan latar belakang pendidikan tinggi mencapai 11,55 persen dari sekitar 64,19 juta jiwa total pemuda Indonesia. Angka tersebut lebih tinggi jika dibandingkan dengan tahun 2018 dan 2017 yang mencapai 11,37 dan 10,14 persen. Hal ini selaras dengan tren meningkatnya perempuan muda yang berstatus sebagai pekerja dari tahun 2017 yang mencapai 39,47 persen menjadi 41,89 persen di tahun 2019. Dengan semakin banyaknya perempuan muda berpendidikan yang berkarier, semakin banyak pula proporsi perempuan muda yang menunda perkawinan dan berstatus single (Himawan 2020; Setyonaluri, Mahgfirah, dan Aryaputra 2020). Di sisi lain, norma-norma seputar perkawinan dan keluarga mengalami - apa yang Nilan (2008) jelaskan sebagai "re-traditionalization" dan "de-traditionalization" di- 
mana generasi muda dihadapkan pada negosiasi-negosiasi dan kontradiksi atas perubahan konteks dimana mereka hidup dan alami. Misalnya, balutan tradisi, agama, dan nilai-nilai konservatif dalam diskursus seputar perkawinan dan keluarga terlihat jelas dalam beragam media budaya populer seperti film - yang dikonsumsi anak muda (Khoiron dan Eliyanah 2020).

Artikel ini bertujuan untuk mengeksplorasi narasi-narasi subjektif dari para perempuan muda dalam mengimajinasikan pasangan ideal dan transisi menuju pernikahan. Bagaimana perempuan muda mengartikulasikan pandangan mereka tentang pasangan ideal dapat memberikan jendela yang unik untuk memahami fenomena relasi gender dalam konteks pembangunan ekonomi dan perubahan sosial-politik yang lebih luas di Indonesia. Apakah pola seperti perempuan menikah dengan laki-laki lebih tua, berpendidikan dan berpenghasilan lebih tinggi masih menjadi dambaan para generasi muda? Pertanyaan ini menjadi penting dalam konteks Indonesia, dimana kami telah melihat kontestasi ide yang sangat nyata seputar pembentukan keluarga: seperti apa formasi keluarga yang ideal, kapan waktu yang tepat untuk menikah, dan apakah pembagian peran gender di dalam pernikahan diperlukan. Melalui pemanfaatan data fieldwork ${ }^{1}$ di Yogyakarta tahun 2019, artikel ini menekankan pada dimensi subjektivitas dan variasi narasi dari setiap subjek dalam memandang mengenai pasangan ideal dan pernikahan.

\section{STUDI-STUDI TERDAHULU}

Artikel ini dibangun berdasarkan pemetaan kajian terdahulu mengenai kaum muda, yang dikhususkan pada subjek perempuan muda dan perubahan sosial dalam pernikahan. Pemetaan kajian-kajian terdahulu secara komparatif dilakukan untuk mengeksplorasi variasi narasi subjektivitas perempuan muda menegosiasikan perubahan sosial dalam pernikahan. Kaum muda dihadapkan pada laju perubahan sosial yang tidak terbendung, namun di sisi lain juga berhadapan dengan tuntutan sosial dan kultural yang masih membelenggu, salah satunya dalam konteks masyarakat Jawa. Negosiasi menjadi penting dalam konteks persilangan antara perempuan muda dalam- laju perubahan dan bayang-bayang kultur dari generasi sebelumnya.

Kajian yang dilakukan oleh Smith-Hefner (2005) tentang transisi pernikahan perempuan Muslim Jawa di Yogyakarta, menemukan banyak perempuan muda yang memilih untuk menunda usia pertama menikah. Menunda menikah adalah salah satu manifestasi dari dampak modernisasi dan perubahan sosial dalam masyarakat Jawa. Perempuan yang semula keterlibatannya hanya terbatas pada sektor domestik kini mendapat kebebasan baru untuk terlibat dalam sektor publik (SmithHefner 2005). Perempuan dapat mengenyam pendidikan hingga jenjang perguruan tinggi, bekerja, dan memilih pasangan idealnya. Akan tetapi meski telah mendapat kebebasan baru, perempuan Muslim Jawa tetap masih harus berhadapan dengan ekspektasi yang disematkan oleh masyarakat terhadap dirinya. Menguatnya ekspresi keagamaan masyarakat Muslim Jawa mendorong implementasi nilai dan ajaran Islam dalam kehidupan sehari-hari. Pembagian peran gender dan relasi antar gender menurut ajaran Islam semakin ditekankan dalam masyarakat. Perempuan Muslim Jawa diharapkan dapat bersikap dan hidup selaras dengan nilai-nilai agama.

Tantangan serupa juga dihadapi oleh kaum muda kelas menengah perkotaan di Indonesia. Nilan (2008) dalam studinya tentang transisi pernikahan kaum muda kelas menengah perkotaan Indonesia menyimpulkan bahwa tengah terjadi 'detradisionalisasi' dan 'retradisionalisasi'. Wacana detradisionalisasi dalam pernikahan nampak dalam aspek ekonomi dan pekerjaan. Perempuan boleh mengenyam pendidikan tinggi dan bekerja, bahkan setelah menikah. Konsep pernikahan yang dipandang ideal adalah pernikahan kemitraan yang setara, perempuan dan laki-laki berbagi peran secara adil dalam rumah tangga. Akan tetapi di sisi lain, kaum muda perkotaan kelas menengah yang berpendidikan tinggi juga menghidupkan kembali praktik dan pemahaman pernikahan tradisional. Hal tersebut diwujudkan dalam cara pandang kaum muda tentang pasangan ideal. Tiga aspek menjadi landasan utama dalam menentukan pasangan ideal: agama dan kepercayaan, latar belakang keluarga, dan kemampuan ekonomi. 
Dalam studinya Utomo et al (2016) menggambarkan tren menuju self-choice marriage dalam memilih pasangan di kalangan generasi muda. Dengan mengambil sampel 1552 responden yang berdomisili di Jakarta, studi ini mendapatkan hanya 4\% yang menikah karena perjodohan. Kaum muda memiliki kebebasan untuk menentukan pasangan yang akan dinikahi. Pernikahan yang diatur oleh keluarga tidak lagi menjadi suatu hal yang banyak dipraktekkan di tengah masyarakat. Akan tetapi meskipun hanya sedikit yang mempraktekkan pernikahan melalui perjodohan oleh orang tua, secara umum, orang tua tetap memiliki peranan utama dalam membuat keputusan pernikahan. Norma-norma yang berlaku di tengah masyarakat menempatkan keluarga sebagai episentrum kehidupan pemuda. Orang tua masih memiliki peranan yang sangat kuat dalam pengambilan keputusan akhir pemilihan pasangan. Tanpa persetujuan orang tua, besar kemungkinan bahwa suatu hubungan percintaan tidak dapat dilanjutkan ke jenjang pernikahan.

Untuk melengkapi studi-studi terdahulu di atas, secara spesifik, artikel ini berkontribusi pada sejauh mana perempuan muda mengaktualisasikan self-choice-nya dalam mengimajinasikan ideal partner untuk pernikahan di masa depan dalam konteks perubahan sosial yang cepat dan masif di Indonesia terutama pada bidang pendidikan. Narasi subyektif perempuan muda dalam artikel ini juga menarik untuk disandingkan dengan narasi-narasi budaya populer seputar pernikahan yang banyak dikonsumsi oleh anak muda. Untuk menyelami narasi-narasi subjektif dari para perempuan muda dalam mengimajinasikan pasangan ideal dan transisi menuju dunia pernikahan, kami memadukan dua lensa teori mengenai perubahan generasi dan postfeminisme.

\section{PERUBAHAN GENERASI}

Kajian kepemudaan global telah banyak memberikan perhatian dalam kerangka kaum muda sebagai sebuah identitas dan budaya (Nilan, Julian and Germov 2007) serta sebagai transisi menuju ke fase kedewasaan (Jones 2009; Wyn and White 1997). Dalam perkembangannya, transisi kaum muda tidak lagi berjalan secara linear, salah satunya diakibatkan oleh perubahan sosial yang cepat dan masif. Kecenderungan ini tidak hanya terjadi pada pengalaman transisi kaum muda di belahan Global North, namun juga di Indonesia (Nilan et al 2011; Minza 2012; Sutopo 2013; Sutopo and Meiji 2014, 2017). Oleh karena itu penting melihat kaitan dengan relasi antar-generasi yang bertujuan memahami setiap peran pemuda yang menjadi ciri khas dari generasi tersebut (Wyn and Woodman 2006). Selain itu, generasi menekankan pada definisi yang disebut sebagai moving target (White 2016: 5), dimana hal ini tidak hanya menyangkut perubahan yang terjadi untuk mendefinisikan sebuah sekelompok orang, tetapi juga perubahan di antara satu generasi dengan generasi selanjutnya. Sutopo (2014: 27) menambahkan bahwa salah satu kontribusi perspektif generasi sosial adalah highlight terhadap dimensi subjektivitas dimana pemuda sebagai agensi menginterpretasikan, mempraktikan, mengkontestasikan serta merespon kehidupan dalam konteks perubahan sosial, ekonomi, budaya serta politik yang sedang dialaminya dengan cara yang baru. Melalui perspektif ini akan terlihat bagaimana pola perubahan dan keunikan serta kompleksitas dari setiap generasi.

Di sisi lain, White (2016) menggambarkan adanya generational change di Indonesia dengan melihat beragam konteks perubahan sosial dan politik. Di mana perubahan pola pendidikan menjadi variabel penting dalam melihat pergeseran antar-generasi dalam transisi menuju dunia kerja dan pernikahan. Peningkatan partisipasi dan durasi waktu dalam domain pendidikan (Parker and Nilan 2013) mengharuskan para pemuda untuk lebih lama bertransisi ke domain lainnya. Dalam konteks pernikahan misalnya terlihat pada perubahan tren usia pada pernikahan pertama (Hull 2003; Jones 2007; Qibthiyyah and Utomo 2016) dan proses pencarian pasangan (Smith-Hefner 2005; Tsutsui 2013) serta pergeseran peran di rumah tangga (Nilan 2008; Utomo 2012) sebagai dampak dari perubahan sosial tersebut.

Selain itu, meningkatnya kesetaraan gender dalam berbagai indikator pembangunan dan masyarakat -terutama dalam aspek pendidikan membawa kontribusi pada pergeseran tren pernikahan. 
Utomo (2014) mencatat tren 'hipergami' - yang merujuk kepada kecenderungan perempuan untuk menikah dengan pasangan yang tingkat pendidikannya lebih tinggi - cenderung semakin menurun. Di tahun 2010 pasangan dengan status proporsi laki-laki lebih tinggi pendidikannya daripada perempuan mencapai sekitar 30 persen, lebih kecil dibandingkan tahun 1982 yang mencapai 40 persen. Sebaliknya, pasangan dengan perempuan yang sedikit lebih tinggi tingkat pendidikannya meningkat dari 10 persen ke 19 persen di tahun 1982 dan 2010 (Utomo 2014). Selain itu, Nilan (2008) menggambarkan pergeseran ke pemahaman non-tradisional dimana kesuksesan pernikahan dilekatkan pada tiga preferensi, yaitu iman, keluarga, dan keuangan. Penekanan lebih kepada financial security yang dikombinasi pada penciptaan ideas tentang keluarga dan keimanan yang merepresentasikan moral dan tatanan sosial serta usaha untuk meminimalisir risiko dalam mengimajinasikan kesuksesan 'domestic' transisi ke pernikahan dan adult life (p. 80). Pola pencarian pasangan juga menunjukkan pergeseran dari budaya perjodohan (arranged marriage) ke selfchoice marriage (Utomo, Reimondos, Utomo, McDonald, \& Hull, 2016). Transisi menuju self-choice marriage di sini menjadi titik masuk, bagaimana perempuan muda di Yogyakarta mengartikulasikan praktik dan makna pilihan mereka dalam proses pencarian pasangan ideal untuk pernikahan di masa depan. Dalam hal ini subjektivitas setiap pemuda mencerminkan keunikan dan ciri khas sekaligus variasi dari generasi mereka serta menjadi gambaran mikro dari pola perubahan generasi.

\section{POST-FEMINISME DAN PILIHAN PEREM- PUAN}

Dalam artikelnya Third Wave Feminism and the Defense of "Choice", Snyder-Hall (2010) menjelaskan bahwa di saat feminisme gelombang kedua mengajak perempuan untuk menolak peran-peran perempuan dalam perspektif femininitas tradisional, feminisme gelombang ketiga (post-feminisme) memperjuangkan dan menekankan bahwa seorang perempuan haruslah dapat memutuskan untuk dirinya sendiri mengenai bagaimana ia menegosiasikan kesetaraan gender dan keinginan untuk berperan dan mengekspresikan diri dalam bentuk-bentuk "sifat feminin tradisional". Femininitas tradisional yang dimaksud di sini adalah karakteristik yang secara normatif dianggap "feminin" seperti domestik, maternal, dan submisif. Menurut McRobbie (2004) hal ini dapat dijelaskan melalui konsep double entanglement. Konsep ini mengeksplorasi post-feminisme sebagai ide-ide yang mengakui ko-eksistensi nilai-nilai neo-konservatisme dalam kaitannya dengan gender, seksualitas, dan kehidupan keluarga (McRobbie 2004). Akan tetapi koeksistensi ideal ini hanya bisa tercapai apabila keputusan-keputusan perempuan untuk hidupnya diambil berdasarkan "kesadaran feminis," yang didefinisikan sebagai "knowledge of what one is doing and why one is doing it" (Baumgardner and Richards 2000).

Meskipun begitu, khususnya dalam konteks Indonesia, nampaknya kesenjangan kelas, identitas, serta aspek interseksional lainnya menentukan tingkat aksesibilitas pengetahuan yang diperlukan untuk memiliki kesadaran tersebut. Faktor penentu lainnya adalah kultur serta kondisi sosial dan politik di dalam masyarakat yang turut mempengaruhi kurangnya kebijakan publik berbasis gender maupun kesadaran masyarakat terhadap opsi-opsi yang dimiliki seorang perempuan. Lekatnya budaya patriarki serta apa yang disebut Connell (2005) sebagai manifestasi hegemonic masculinity dalam masyarakat membuat gambaran normatif keluarga yang terdiri dari ayah yang bekerja dan ibu yang mengurus rumah tangga turut pula menunjang kondisi tersebut.

Pendidikan tinggi yang didapatkan oleh perempuan sebagai buah dari perubahan sosial dan peningkatan pembangunan ekonomi di Indonesia tidak lantas menjadi variabel yang sepenuhnya membebaskan dari belenggu budaya dominan. Tuntutan serta stigma perempuan masih melekat dan eksis bersamaan dengan perubahan sosial yang telah terjadi dalam masyarakat. Smith-Hefner (2019) mengungkapkan bahwa term tentang "kodrat" yang dipromosikan dalam pemerintahan Orde Baru masih sering dibaringkan di dalam wacana gender. Perbedaan gender yang menyangkut peran, tanggung ja- 
wab, serta otoritas masih membayangi hingga saat ini. Di sisi lain, tuntutan dan ekspektasi orang tua juga turut serta mewarnai imajinasi dan aspirasi perempuan muda, terutama dalam hal pemilihan pasangan ideal untuk pernikahan di masa depan.

\section{METODE PENELITIAN}

Artikel ini bertumpu pada sebagian data yang dikumpulkan melalui penelitian tentang perubahan pola berpasangan dan perkawinan di Jogjakarta dan Kabupaten Gunung Kidul pada tahun 2019. Penelitian ini menggunakan metode kualitatif dengan wawancara mendalam (in-depth interview, dengan 20 informan) dan Focus Group Discussion (FGD, yang melibatkan 20 informan) sebagai teknik pengumpulan data. In-depth interview digunakan untuk menggali dan mengeksplorasi narasi subjektif serta pengalaman para informan terkait dengan percintaan dan pandangan serta aspirasi kriteria pasangan di masa depan. Dimana pandangan tersebut dipengaruhi oleh perubahan sosial yang dihadapi oleh generasi muda sekarang dan bayang-bayang budaya generasi sebelumnya. Sedangkan FGD digunakan untuk mengumpulkan serta mengkonfirmasi isu-isu yang terkait dengan tema sehingga didapatkan gambaran secara umum yang mewakili kekhasan dari generasi para informan.

Berangkat dari analisis data keseluruhan dari penelitian ini, informan dalam artikel ini difokuskan pada empat perempuan muda yang mengenyam bangku perguruan tinggi. Pemilihan informan didasarkan pada pemilihan model intrinsic dengan menekankan pada keunikan subjek yang menarik perhatian khusus dari peneliti (Crowe et al 2011). Dimana keunikan yang dimaksud didasarkan pada perbedaan latar belakang dari setiap informan dan pemaknaannya terhadap pernikahan masa depan. Secara purposive didapatkan dua informan yang merupakan mahasiswi perguruan tinggi yang tinggal di Kota Yogyakarta, serta dua informan lain yang berasal dari dan berdomisili di pedesaan di Kabupaten Gunung Kidul namun berkuliah di Kota Yogyakarta. Setiap informan mempunyai karakteristik masing-masing dengan narasi yang beragam sehingga didapatkan hasil analisis yang lebih komprehensif.

\section{EMPAT NARASI PEREMPUAN MUDA}

1. Riri

Riri adalah mahasiswa Ilmu Manajemen di salah satu perguruan tinggi swasta Islam di Yogyakarta. Dara kelahiran Yogyakarta tahun 1998 ini telah menghabiskan sepanjang hidupnya di Yogyakarta. Sejak Taman Kanak-Kanak (TK) hingga Sekolah Menengah Atas (SMA) Riri selalu mengenyam pendidikan di sekolah negeri. Berkuliah di perguruan tinggi swasta Islam bukanlah pilihan utamanya, ia memutuskan untuk berkuliah di perguruan tinggi tersebut setelah tidak diterima di perguruan tinggi pilihannya. Saat hendak memulai tahun pertamanya sebagai mahasiswa, Riri sempat dilanda kekhawatiran tidak dapat beradaptasi dengan budaya pendidikan di sekolah berbasis agama. Namun lambat laun Riri bisa beradaptasi dengan baik dan menemukan kenyamanan. Keputusan berkuliah di perguruan tinggi berbasis agama rupanya selaras dengan dinamika dan transisi yang dijalani oleh keluarganya dalam beberapa tahun terakhir.

Riri terlahir sebagai anak semata wayang keluarga kelas menengah Muslim. Kedua orang tuanya berasal dari Yogyakarta dan sama-sama memiliki latar belakang keluarga yang nasionalis dan tidak terlalu ketat dalam menjalankan syariat Islam. Identitas lama keluarga Riri direfleksikan melalui dukungan mereka terhadap partai politik tertentu yang kerap disebut sebagai partai nasionalis. Akan tetapi seiring berjalannya waktu, keluarga Riri bertransisi menjadi keluarga Muslim yang taat. Saat Riri masih duduk di bangku SMA, ibunya mulai aktif menghadiri kajian agama rutin dan tergabung dalam salah satu perkumpulan Muslimah di Yogyakarta.

"Jadi dulu orang tuaku biasa aja soal agama. Ya ga terlalu gimana-gimana gitu, biasa aja lah pokoknya. Terus mulai aku SMA, lupa kelas berapa, Mamaku mulai aktif ikut kajian gitu, terus ya udah lama-lama mulai belajar buat memperdalam agama." (Wawancara Riri, 2019).

Transisi keluarga Riri menjadi keluarga Muslim yang taat berdampak pada berbagai aspek kehidupan Riri, termasuk dalam hal mencari jodoh. Semula Riri sangat mengutamakan penampilan fisik, 
latar belakang ekonomi, dan kemampuan sosial seorang pria. Namun indikator-indikator tersebut menjadi tidak penting setelah keluarganya bertransisi menjadi lebih religius. Pada saat wawancara dilakukan, Riri hanya memiliki satu kriteria, yaitu suaminya kelak haruslah taat beribadah dan memiliki pemahaman agama yang mendalam. Orang tua Riri, khususnya sang ibu, juga sangat menekankan pada Riri untuk mencari pasangan hidup yang taat beragama.

"Orang tuaku, terutama mamaku sih yang nekanin hal itu (pasangan yang taat beragama). Apalagi aku kan anak tunggal, jadi pengennya mama, aku bisa dapet suami yang bisa membimbing aku. Sebenarnya keluargaku juga ga dari dulu sih setaat ini, ini juga lagi proses buat beragama yang lebih baik. Pokoknya yang paling utama ya harus bisa dapet yang agamanya bagus." (Wawancara Riri, 2019).

Ketaatan beragama adalah syarat mutlak yang harus dimiliki oleh suami Riri kelak. Untuk aspek lain seperti kelas sosial dan tingkat pendidikan Riri tidak punya kriteria yang spesifik. Ia pun tidak mempermasalahkan bila tingkat pendidikan suaminya kelak lebih rendah dari dirinya selama pasangannya berwawasan luas.

"Engga. Pokoknya kalau agamanya bagus ya udah ga ada masalah lain. Lagian dari pengalamanku dan lihat teman-temanku di kampus belum tentu kok yang lulusan S1 lebih pintar dari yang cuma SMA. Aku sih ga mentingin gelar, yang penting wawasannya. Ya kan sama aja juga kalau dia lulusan tinggi tapi ga punya wawasan luas. Aku lebih mending cuma lulusan SMA tapi wawasannya luas dan mau belajar." (Wawancara Riri, 2019).

Riri memang tidak memiliki kriteria lain selain ketaatan beragama, namun Riri sangat berharap bahwa suaminya kelak adalah orang Yogyakarta. Sebagai anak tunggal, Riri merasa memiliki kewajiban untuk menjaga kedua orang tuanya. Ia sangat berkeinginan untuk bisa berkeluarga dan tinggal di Yogyakarta demi ayah dan ibunya.

"Ya sebenernya siapapun bisa sih cuma lebih baik kalau dapat orang Jogja, Mamaku juga bilangnya gitu. Kalau sama-sama orang Jogja kan enak, aku masih bisa ngurusin orang tuaku, dia juga masih bisa ngu-- rusin orang tuanya." (Wawancara Riri, 2019)

Dari penuturannya, tergambar bahwa Riri masih membuka peluang bagi laki-laki di luar Jogja, namun Riri tetap berharap mendapat jodoh yang berdomisili di satu wilayah yang sama. Selain mempertimbangkan aspek 'berbakti' dan "kewajiban" sebagai seorang anak tunggal, keputusan Riri merupakan win-win solution untuk pasangannya agar bisa merawat dan dekat dengan orang tuanya.

\section{Diana}

Diana adalah mahasiswa Pascasarjana ilmu sosial di salah satu perguruan tinggi negeri di Yogyakarta. Perempuan kelahiran 1994 ini menghabiskan waktu kanak-kanak dan remajanya di Malang, Jawa Timur. Setelah lulus SMA, Ia memutuskan untuk kuliah di Yogyakarta. Selain disibukkan dengan perkuliahan, Diana juga aktif mengikuti kegiatan-kegiatan sosial khususnya terkait dengan pendampingan difabel. Hal ini membuatnya cukup mempunyai jaringan peer-group yang beragam dan memberikannya banyak insight serta pola pikir yang lebih bersifat terbuka.

Dalam hal percintaan, seperti banyak anak muda seusianya, Diana juga menjalin hubungan spesial dengan seorang laki-laki. Bagi Diana, kecocokan satu sama lain adalah landasan penting dalam memutuskan sebuah hubungan sebagai sepasang kekasih. Namun, Ia mempunyai definisi sendiri mengenai hal tersebut:

"Cocok dalam artian aku sama dia punya ketertarikan yang berbeda, punya cara pandang yang nggak selalu sama juga, tapi bagaimana kita kemudian sama-sama bisa saling menegosiasikan itu, menurutku itu yang penting. Karena kalau misalkan dalam hubungan jangka panjang, kita nggak bisa memastikan kalau kita akan selalu ada di track yang sama, dalam konteks pemikiran dengan pasangan kita, gitu." (Wawancara Diana, 2019)

Diana memang sangat menekankan kriteria yang lebih kepada personal character daripada personal background. Ini juga menjadi alasan dimana perbedaan agama tidak menjadi permasalahan dalam hubungannya sekarang. Namun, tentu Ia menyadari itu akan membawa masalah bagi keluarganya. Diana 
tumbuh di keluarga yang, menurutnya, semakin hari semakin religius. Bagi keluarganya, kemapanan ekonomi bukan menjadi masalah besar - dalam konteks ini Ia menyetujui, namun pandangan dan latar belakang agama sulit untuk ditawar.

"So far sih kalau misalkan mereka, sejauh yang aku tahu ya, buat mereka yang paling penting adalah agamanya sama. Mau dia bekerja apakah dia sudah mapan secara ekonomi atau belum itu tidak menjadi masalah. Karena keluargaku sendiri dan saudaraku yang lain nggak terus mereka dari latar belakang ekonomi yang mapan gitu." (Wawancara Diana, 2019).

Permasalahan tersebut bukan hanya terkait dengan restu yang akan sulit didapat tetapi juga gejolak perbedaan antara dirinya dengan orang tuanya. Ia menuturkan keinginan untuk mandiri secara pemikiran dan pandangan - ini termasuk menyangkut kemungkinan bahwa Ia akan memutuskan menganut agama yang berbeda dengan orang tuanya. Dalam konteks ini, Diana secara refleksif menyadari bahwa dalam budaya dimana la tinggal, keterlekatan dengan keluarga memang sulit untuk dihindari. Oleh sebab itu, Ia tidak bertindak gegabah dalam mengekspresikan pandangannya.

\section{Cici}

Perempuan berusia 20 tahun ini merupakan mahasiswa di salah satu perguruan tinggi swasta di Yogyakarta. Cici panggilan akrabnya, mengambil Ilmu Akuntansi sebagai bidang studi yang digeluti saat ini. Meskipun berkuliah di Yogyakarta, Cici memutuskan untuk tetap tinggal di desanya yang berada di Kabupaten Gunung Kidul. Tiga hingga empat hari setiap minggunya Ia harus menempuh jarak sekitar $50 \mathrm{Km}$ untuk mengikuti perkuliahan. Dengan sistem nglaju, Cici tidak hanya bisa aktif di kampusnya, tetapi juga berhasil mengambil peran yang diharapkan sebagai pemudi di desanya. Ia aktif di organisasi Karang Taruna dengan berbagai kegiatan seperti seni-budaya dan sosial.

Tidak seperti beberapa pemuda-pemudi lainnya, Cici tidak begitu tertarik merantau atau meninggalkan desanya untuk urusan pendidikan atau kerja. Sejak kecil Ia tumbuh dengan asuhan orang tua yang juga berasal dari desa yang sama. Sebagian besar tahapan kehidupan Ia habiskan di desa dan beberapa wilayah sekitarnya. Jenjang pendidikannya, dari tingkat dasar hingga menengah ke atas, Cici mengambil sekolah yang berjarak tidak jauh dari tempat tinggalnya. Hal ini menjadi faktor mengapa keterlekatan dengan tempat tinggal cukup kuat bagi Cici dalam memutuskan, salah satunya pandangan mengenai pasangan hidup.

"Kalau saya, jangan jauh-jauh mbak. Yang penting nggak sedesa. Tapi kalau ketemunya yang di desa ya bagaimana lagi? Kasian orang tua kalau jauh" (Wawancara Cici, 2019).

Menurut Cici, latar belakang kota asal si calon menjadi pertimbangan yang cukup penting. Hal ini didorong oleh pertimbangan bahwa orang tua akan mengalami kesulitan untuk menemui anak-cucunya. Pertimbangan ini cukup wajar, jika dikontekstualisasikan dengan kultur kekeluargaan yang masih melekat di sebagian besar orang Jawa. Dimana keterikatan orang tua dengan anak, cucu, dan menantu masih terjalin kuat, bahkan setelah menikah. Namun, bagi Cici, berjodoh dengan laki-laki satu desa juga menjadi kejanggalan dalam hatinya. Menurutnya, tidak adanya jarak atau jarak yang terlalu dekat cenderung akan mengganggu keharmonisan rumah tangga karena intensitas pertemuan dan tingkat ketergantungan dengan orang tua terlalu tinggi. Oleh karena itu, berbeda Kecamatan atau Kabupaten namun masih dalam satu provinsi menjadi kriteria ideal.

Sebagai perempuan yang mempunyai latar belakang pendidikan tinggi, Cici tentu juga mempunyai kriteria lain untuk persoalan pasangan hidup. Baginya, level pendidikan tidak masuk dalam check list-nya. Jikapun pasangannya nanti berpendidikan SMA, Cici tidak merasa keberatan, meskipun dalam pengalamannya pihak laki-laki cenderung akan lebih minder. Cici justru menegaskan bahwa kemapanan ekonomi lebih penting dibandingkan latar belakang pendidikan. Baginya, tidak ada jaminan gelar sarjana mampu memberikan penghidupan yang layak di masa depan.

"Yang jelas mapan. Soalnya kalau jaman sekarang, kalau nggak mapan, si cewek nanti kalau menderita bagaimana? Kan kita pikirannya juga harus logis kan sebagai wanita. Nanti kedepannya itu harus punya 
suami yang sudah jelas kerjaannya, terus sudah jelas pendapatannya buat kita. Jadi, saya ini cuek kalau perempuan dibilang matre. Saya cuek" (Wawancara Cici, 2019).

Berdasarkan penuturannya, kemapanan ekonomi pasangan - dengan berpendapatan stabil dan pekerjaan yang jelas akan lebih menjamin kehidupannya setelah menikah. Bagi Cici, standar tersebut adalah hal yang logis, meskipun risiko stigma "perempuan matre" yang masih mengakar di sebagian besar kalangan masyarakat berpotensi dilekatkan padanya.

\section{Yati}

Yati adalah seorang perempuan muda berusia 20 tahun yang berasal dari sebuah dusun kecil di Kabupaten Gunung Kidul. Latar belakang Yati tidak jauh berbeda dengan para pemudi di kampung halamannya. Seperti keluarga lainnya, orang tua Yati bekerja serabutan serta mengandalkan hasil bercocok tanam untuk menopang kehidupan keluarga. Namun berbeda dengan pemudi sepantarannya, Yati memiliki kesempatan mengenyam bangku pendidikan tinggi. Melanjutkan ke perguruan tinggi bukanlah hal yang lazim dilakukan oleh pemudi di dusun Yati. Para pemudi umumnya langsung bekerja, atau menikah begitu menamatkan bangku SMA/ sederajat.

Saat ini Yati tercatat sebagai mahasiswa Ilmu Manajemen di salah satu perguruan tinggi swasta di Yogyakarta. Karena jarak antara rumah dengan kampus yang sangat jauh, Yati memutuskan untuk menetap di Yogyakarta. Namun bagi Yati yang lahir dan besar di dusun yang masih guyub dan rukun, tinggal sendirian di Yogyakarta tidak mudah dilakukan. Oleh karena itu sejak semester 4 Yati memutuskan kembali menetap di kampung halaman. Ia lebih memilih menempuh jarak 100 kilometer pulang-pergi, 4 kali dalam seminggu, daripada tinggal jauh dari kampung halamannya.

Kecintaan Yati pada kampung halamannya terefleksikan dalam cara pandang Yati tentang kriteria yang ia miliki untuk pasangan hidupnya di masa depan. Yati berharap pasangannya kelak berasal dari desa yang sama atau desa tetangga. Namun bila kelak pasangannya berasal dari daerah lain, Yati ingin agar ia mau diajak menetap di desa. Yati ingin terus menetap di desa karena sebagai anak perempuan terakhir di keluarganya, Yati memiliki tanggung jawab untuk merawat kedua orang tuanya saat mereka kelak menjadi renta.

"Kalau saya pribadi sih dari orangtua, saya kan anak terakhir dari tiga bersaudara jadi dibilangin, 'kamu tu anak terakhir, mau ga mau kamu yang ngurus orang tua.' Jadi entah nanti dapat orang mana, semisal bukan dari sini, ya harus yang mampu menerima saya dan orangtua saya, kemudian hidup bersama saya di sini." (Wawancara Yati, 2019).

Akan tetapi, walaupun keinginannya untuk mendapatkan pasangan hidup dari desa yang sama atau desa tetangga dilandasi oleh keinginan untuk menjaga tradisi, Yati tidak terlalu mementingkan bibit, bebet, bobot ${ }^{2}$ pasangannya kelak. Menurut Yati perkara tinggi atau rendahnya kelas sosial ekonomi dan tingkat pendidikan pasangannya kelak tidak penting selagi pria tersebut adalah pribadi yang bertanggung jawab.

"Kalau menurut saya sih gak penting mau laki-laki itu lebih tinggi atau rendah tingkat pendidikannya dari saya. Karena kalau menurut saya laki-laki yang penting tanggung jawabnya yang pertama, dan juga bagaimana dia itu mampu memimpin keluarganya. Jadi semisal memimpin keluarganya tuh ya mereka bisa memimpin dirinya sendiri terlebih dahulu, baru nanti bisa memimpin keluarganya. Kalau misal perempuan, saya sendiri itu kuliah. Kan nantinya yang lebih mendidik anak kan perempuan, jadi bagaimana perempuan mampu menjadi madrasah pertama bagi anaknya itu yang penting. Ya tanggung jawab laki-laki menafkahi, tapi kan kalau mendidik tanggung jawab lebih fokusnya ke ibu." (Wawancara Hayati, 2019)

Cara pandang Yati yang tidak terlalu rigid berpaku pada tradisi pemilihan jodoh merupakan refleksi atas pendidikan yang ia tempuh. Kala temanteman sepantarannya enggan memiliki pasangan yang memiliki latar belakang lebih rendah, Yati tidak berpikiran demikian. Baginya terdapat kualitas lain yang jauh lebih penting ketimbang hal-hal yang bersifat materiil. Selain itu hal lain yang mencerminkan tingkat pendidikannya adalah pandangan tentang usia yang tepat untuk menikah. Berbeda dengan teman-teman sepantarannya yang cenderung memi- 
lih menikah di usia muda, Yati merasa bahwa menikah di usia muda kurang tepat. Menurutnya pernikahan membutuhkan kedewasaan dan kematangan berpikir, sehingga akan lebih baik bila seseorang menikah setelah menginjak usia dewasa.

"Kalau misal nikah umur 25 kan lebih matang, nah selain itu saya pernah ikut Forum Anak. Di Forum Anak ada studi banding perkumpulan teman-teman membicarakan bagaimana dampak nikah usia muda di lingkungan sekitarnya. Kalau dari cerita temanteman, nikah muda itu ibaratnya masa seharusnya teman-teman bisa main sama saya malah sudah mengasuh anak. Otomatis dari situ hak-hak anak juga ga terpenuhi. Jadi mungkin kalau nikah umur 25 itu mungkin sudah dewasa, jadi sudah matang." (Wawancara Yati, 2019).

Pandangan Yati terhadap ide mengenai pernikahan memang belum sepenuhnya lepas dari perspektif tradisional, terutama dalam hal pembagian peran dalam pernikahan. Hal ini mencerminkan masih kuatnya ikatan emosional Yati dengan budaya di tempat ia tumbuh dan dibesarkan. Namun, pengalamannya mengenyam pendidikan tinggi di kota dalam taraf tertentu memberikan Yati kemampuan untuk berfikir secara lebih rasional mengenai usia pernikahan yang ideal serta logika mengenai fase perkembangan anak dan kaum muda.

\section{TREN (BARU?) SUAMI IDEAL}

Peningkatan tren perempuan berpendidikan tinggi membawa perubahan yang cukup signifikan pada pola-pola pernikahan. Jika sebelumnya didominasi oleh term hypergamy - historic dan global tendency pada perempuan untuk menikah dengan laki-laki yang status sosial-ekonominya lebih tinggi (Utomo 2014), generasi 1990-an cenderung menunjukkan pola yang berbeda. Dengan meningkatnya akses perempuan dalam pendidikan tinggi, semakin banyak pula pasangan muda dimana pendidikan istri sedikit lebih tinggi dari suami. Smith-Hefner (2019: 145) menjelaskan bahwa tren ini adalah gambaran anxieties yang diciptakan dari mobilitas sosial baru dan peluang ekonomi dari mayoritas kelas menengah di Indonesia. Peluang dan perubahan ini menggiring pada kondisi yang Smith-Hefner sebut sebagai "marriage crisis".

Hal ini yang mendorong keempat informan, melalui latar belakang pendidikan tingginya, mereka lebih fokus untuk mengidentifikasi laki-laki yang bisa bernegosiasi dengan peran kerja dan keluarga dalam konteks modernitas lanjut. Mereka telah membuat penyesuaian antara strategi dan ekspektasi dalam proses pencarian pasangan yang sesuai. Narasi dari Diana misalnya, di usianya yang ke 26 tahun, Ia berhasil mendapat gelar sarjana dan sedang menempuh pendidikan master. Mereka menunjukkan pola yang sama, dimana level pendidikan pasangan bukan bagian dari kriteria penting. Beberapa informan justru memberikan peluang bagi laki-laki dengan level pendidikan lebih rendah. Di sisi yang lain, masing-masing justru menunjukkan imajinasi pada penggambaran yang lebih spesifik sebagai bagian dari strategi dan negosiasi dalam menghadapi - dan atau bagian dari perubahan sosial yang cepat dan masif (Wyn and Woodman 2006; Sutopo 2014).

Cici misalnya, lebih menekankan pada financial security setelah menikah daripada mempunyai level pendidikan tinggi, Ia menuntut calon pasangannya mempunyai pekerjaan yang mapan dengan pendapatan yang tetap. Kriteria ini adalah bagian dari upaya Cici untuk mengurangi risiko uncertain financial condition setelah menikah. Cici merupakan bagian dari pemuda usia menikah yang mengalami periode krisis ekonomi yang mengerikan bersamaan dengan pertumbuhan konsumsi tanpa batas yang terselebrasi (Nilan 2008: 79). Dengan pasangan yang mapan secara ekonomi, hal ini menjadi strategi reflektif dari Cici untuk keluar dari kesulitan ekonomi setelah menikah. Kekhawatiran ini menjadi wajar dalam konteks ruang dan pengalaman Cici dalam proses transisi sebelumnya. Kondisi ekonomi keluarga yang tidak menjamin kehidupannya setelah menikah dan pengalaman orang-orang di wilayahnya, mengharuskan Cici untuk memastikan bahwa pasangan hidupnya kelak mampu memberikan penghidupan yang layak. Begitu juga dengan Yati, meskipun tidak secara terang-terangan menyebutkan kriteria kemapanan ekonomi untuk pasangannya, Ia masih menempatkan laki-laki pada posisi pencari 
nafkah di dalam keluarga.

Narasi dari Diana misalnya, personal background seperti ekonomi, atau bahkan identitas agama, tidak menjadi persoalan. Ia lebih menavigasikan pada karakter pasangan yang bisa mengimbanginya. "cocok" dan "nyambung" menjadi kata kunci penting, artinya bahwa kepribadian pasangan menentukan ketertarikan Diana pada lawan jenisnya. Sama halnya dengan Riri yang lebih menekankan pada term saleh sebagai syarat mutlak daripada latar belakang ekonomi untuk pasangannya. Ia adalah anggota 'baru' dari kelompok kelas menengah muslim taat yang merupakan produk dari gelombang islamisasi yang menguat di kalangan keluarga kelas menengah di Indonesia belakangan ini (Weintraub 2011; Heryanto 2011; Jati 2017). Dalam temuannya, Nilan (2008) mengungkapkan bahwa kriteria suami yang sabar, sederhana, jujur, baik, bertanggung jawab, dan mampu memahami menggambarkan wacana tentang suami ideal dan seimbang, dimana hal ini sebagai strategi reflektif untuk meminimalisir risiko perceraian (Heaton, Cammack, and Young 2001) - atau ketidakcocokan setelah menikah. Nilan juga menemukan bahwa term saleh/taat (devout) menjadi bagian dari 're-traditionalization' atau bahkan 're-sacralisation' dari proses mengimajinasikan pasangan.

\section{KEMBALI PADA TRADISI JAWA DAN KET- ERLEKATAN KELUARGA}

Tren tradisi arranged marriage semakin menunjukkan penurunannya (Tsutsui 2013; Utomo et al. 2016), generasi muda, baik perempuan maupun laki-laki telah memiliki kebebasan dalam memilih dan mengimajinasikan pasangannya. Tsutsui (2013) misalnya, memberikan gambaran pertumbuhan partisipasi pendidikan dan peningkatan ekonomi di negara-negara Asia dalam memberikan dorongan pada kaum muda untuk bebas menentukan pernikahan dan kriteria pasangan.

Dalam konteks lokal, Smith-Hefner (2005) mengungkapkan bahwa tradisi Jawa juga telah mengalami banyak perubahan terutama dalam konteks pernikahan sebagai salah satu dampak dari pemban- gunan di sektor pendidikan dan perubahan sosio-politik Islam di Jawa. Sebagian besar orang tua Jawa telah memberikan kebebasan pada anaknya untuk memilih pasangannya. "The times have changed', Javanese parents say, 'this is the modern era' (Smith-Hefner 2005: 448). Tradisi bibit-bebet-bobot yang khas diterapkan generasi orang tua Jawa pada beberapa dekade yang lalu mulai bergeser.

Meskipun demikian, studi Utomo et al. (2016) menunjukkan melalui kajian dengan 1552 responden di Jakarta bahwa lebih dari separuh responden mengakui jika orang tua masih berperan besar dalam memutuskan pernikahan. Tidak hanya itu, orang tua juga berperan besar untuk memberikan kontribusi dalam membentuk kriteria atau dengan siapa seseorang menikah (Tsutsui 2013). Dalam kasus Riri dan Diana misalnya, perubahan religiusitas keluarga berdampak besar pada pembentukan persepsi pasangan ideal bagi Riri. Tidak berbeda, persepsi yang dipupuk berdasarkan pengalaman banyak anggota keluarga terhadap persoalan financial security juga menjadi alasan Diana untuk membuka peluang adanya marrying-down. Namun, di sisi lain, nilai-nilai keluarga yang melekat kuat berbenturan dengan semangat 'menjadi modern dan berpikiran terbuka' sebagai produk dari pendidikan mengharuskan mereka melakukan negosiasi-negosiasi - yang memunculkan kekhasan serta variasi-variasi sebagai representasi generasi kontemporer (Sutopo 2014).

Dalam konteks tradisi Jawa khususnya, keterlekatan keluarga justru tidak hanya akan mempengaruhi pilihan, tetapi juga menyangkut proses memilih pasangan - dari pemilihan adat pesta hingga pembiayaan (Smith-Hefner 2019) serta rencana setelah menikah. Meskipun demikian, keterlekatan budaya Jawa tidak sepenuhnya menghilang selaras dengan pendidikan yang meningkat diakses oleh laki-laki, bahkan perempuan. Dalam konteks tertentu masih melekat di sebagian generasi muda, budaya seperti yang dituliskan Wolf (1992:57-58) dalam studinya, bahwa ketika perempuan menikah, pada umumnya akan tinggal bersama orang tua (matrilocality - pihak perempuan) ${ }^{3}$ dalam satu rumah hingga 
5 atau 10 tahun. Mereka akan lepas dari orang tua dan hidup secara mandiri setelah mempunyai rumah - tentu pada banyak kasus dengan bantuan finansial dari orang tua. Dalam kondisi tertentu, seperti anak terakhir perempuan atau anak tunggal mengharuskan mereka untuk tinggal dengan orang tua setelah menikah (sering disebut sebagai kumpulan).

Jika Smith-Hefner (2019:144) menempatkan sistem "mbalas budi" pada tanggung jawab sosial pada orang tua yang telah membesarkan, mencintai, membiayai kebutuhan termasuk pendidikan dengan mengambil peran pada pembiayaan sekolah adik-adiknya atau kebutuhan ekonomi lainnya, hal yang berbeda justru terjadi pada Yati yang harus rela untuk tinggal bersama orang tuanya setelah menikah. Tuntutan ini menjadi bagian dari bentuk bagaimana Yati membalas jasa-jasa orang tuanya. Sebagai anak tunggal, orang tuanya hanya memusatkan perhatian dan kasih sayangnya pada Yati. Hal ini juga mendorong tanggung jawab Yati untuk mengambil peran penuh untuk menemani orang tuanya di masa-masa tua. Oleh karena itu, Ia menekankan pada kriteria pasangan yang bersedia tinggal bersama orang tuanya. Variasi pemaknaan subjektif lain muncul dari Cici, Ia cenderung menegosiasikannya melalui skema "tidak tinggal satu desa, namun juga tidak jauh dengan orang tuanya". Hal ini memungkinkan dirinya untuk tetap dekat secara spasial, namun juga terlihat mandiri dan tidak terus menerus diintervensi oleh orang tua.

Alih-alih mengimajinasikan mobilitas yang lebih fleksibel sebagai cerminan generasi muda di era modernitas lanjut, pada konteks pemuda desa, budaya tersebut cenderung masih lebih kuat. Meskipun dalam kondisi tertentu kebutuhan mobilitas tetap dilakukan seiring dengan tuntutan upgrading status pendidikan dan kerja; keterlekatan dan tanggung jawab 'moral' pada orang tua masih menjadi variabel dalam transisi menuju pernikahan. Hal ini setidaknya menjadi umum di kalangan pemuda desa tempat tinggal Cici dan Yati.

"Kalau disini sudah tradisi sih (tinggal bersama dan mengurus orang tua), tapi kebanyakan ga harus anak terakhir. Tergantung orangtuanya. Tapi kebanyakan anak terakhir yang tinggal, apalagi cewek. Anak terakhir cewek disuruh tinggal di rumah." (Wawancara Yati, 2019).
Keputusan-keputusan informan dalam memilih untuk menjalani hidup sebagai perempuan sesuai tradisi bukan berarti adalah jalan pintas (Ferguson 2010). Dari temuan-temuan di atas, dapat disimpulkan bahwa kesadaran perempuan atas pilihan-pilihan hidup yang dimilikinya masih merupakan cita-cita ideal yang masih terus diperjuangkan di Indonesia, khususnya Yogyakarta. Konsep Post-Feminisme, terutama yang dideskripsikan dengan terminologi "choice feminism" (Hirshmann 2006), belum secara tepat mampu untuk mengilustrasikan konteks perempuan muda yang mengambil keputusan berdasarkan kewajiban agama, tradisi serta realita kelas dan kebutuhan ekonomi. Bahkan, menurut Ferguson (2010), terminologi ini cenderung mencampuradukkan dengan opsi-opsi yang bersifat "elektif" seperti berpose untuk majalah dewasa atau memakai lipstik dan sepatu hak tinggi. Lebih jauh lagi, Snyder-Hall (2010) menjelaskan bahwa meskipun konsep ini berkomitmen terhadap prinsip-prinsip seperti pluralisme, self-determination, dan nir-penghakiman, namun tetap dianggap problematis karena berpotensi mengecilkan keputusan-keputusan sulit yang harus diambil perempuan. Retorika "choice" mengalihkan fokus dari kondisi-kondisi dimana pilihan perempuan seringkali dibatasi dan diputuskan secara paksa oleh struktur sosial dan tradisi kultural yang berlapis: sebuah keadaan yang ingin diubah oleh feminisme (Snyder-Hall 2010). Alih-alih harus memilih antara berkarier atau berkeluarga, opsi-opsi bagi perempuan seharusnya diperluas agar mereka secara refleksif dapat menentukan nasibnya sendiri (self-determining).

\section{KESIMPULAN}

Dalam konteks Indonesia, pernikahan masih dianggap sebagai momen penting transisi pemuda menuju fase kedewasaan. Dalam perkembangannya, pembangunan ekonomi yang disertai dengan perubahan sosial di masyarakat telah mendorong pergeseran makna dan tradisi dalam proses menuju pernikahan dari generasi ke generasi. Akses pendidikan tinggi dan mobilitas yang lebih luas memberikan jukstaposisi kebebasan bagi para perempuan muda: Mereka bebas memilih calon pasangannya 
sendiri, tetapi baik secara sadar maupun tidak, sedikit maupun banyak, langsung maupun tidak langsung, kebebasan tersebut masih dipengaruhi oleh nilai normatif yang dianut oleh keluarga dan lingkungan mereka yang masih memegang tradisi ke-Jawa-an. Hal ini ditambah dengan budaya filial piety $^{4}$ yang masih kuat ditanamkan di Indonesia menunjukkan bahwa "kesadaran feminis" masih merupakan sebuah privilese. Meningkatnya akses terhadap pendidikan formal, baik bagi perempuan muda secara umum maupun di pedesaan, belum dapat menjamin kesadaran seorang perempuan mengenai feminitas tradisional sebagai pilihan. Terlebih lagi kesadaran mengenai pilihan-pilihan di luar femininitas tradisional masih belum seutuhnya dimiliki oleh banyak perempuan Indonesia. Keempat informan yang menjadi subyek penelitian ini tidak serta merta menggeneralisasi keadaan masyarakat Yogyakarta maupun Indonesia. Akan tetapi, temuan dan simpulan dari penelitian ini diharapkan dapat menjadi referensi mengenai bagaimana perempuan dari generasi muda kontemporer membayangkan dan memaknai secara subyektif wacana tentang pernikahan, posisi mereka sebagai perempuan serta faktor-faktor struktural dan kultural yang melatarbelakanginya. Ke depan, menurut kami, penelitian ini dapat dikembangkan lebih lanjut terkait dengan negosiasi pemuda dan pernikahan dalam konteks budaya lokal di luar tradisi Jawa misalnya Sulawesi, Bali dan $\mathrm{Su}^{-}$ matra dimana adat masih melekat kuat dan seringkali menjadi hambatan kultural berlapis bagi kebebasan kaum muda dalam menentukan pasangan hidupnya.

\section{NOTES \\ ${ }^{1}$ Fieldwork ini merupakan bagian dari penelitian dengan judul "Who Marries Whom: Marriage Development and Social Change in Indonesia" yang dilakukan di beberapa kota, ter- masuk Yogyakarta dan Gunung Kidul pada tahun 2019.}

${ }^{2}$ Merupakan tradisi Jawa yang berupa ilmu memilih jodoh

3 Dalam beberapa kasus pasangan Jawa juga menerapkan patrilokal - tinggal dengan pihak keluarga laki-laki, atau skema lainnya adalah 'ngalor-ngidul' - bergantian dari rumah pihak laki-laki ke pihak perempuan (Koentjaraningrat 1985)

${ }^{4}$ Budaya yang menganggap anak harus menuruti kemauan orang tua sebagai bentuk terima kasih atas pengorbanan mereka melahirkan kita ke dunia (Lam 2019; Setiyani \& Windsor 2019).

\section{DAFTAR PUSTAKA}

Afrianty, Dina. 2020. "Rising Public Piety and The Status of Women in Indonesia TwoDecades After Reformasi". TRaNS: Trans-Regional and - National Studies of Southeast Asia, Vol 8 (1), 65-80

Badan Pusat Statistik. 2019. Indonesia dalam Angka. Jakarta: BPS.

Badan Pusat Statistik. 2019. Statistik Pemuda Indonesia 2019. Jakarta: BPS.

Baumgardner, Jennifer and Amy Richards. 2000. Manifesta: Young Women, Feminism, and the Future. New York: Farrar, Straus and Giroux.

Choiron, Nabhan F. and Evi Eliyanah. 2020. "Who Marries Whom on Silver Screen? Religion And Social Class In Marriage Patterns In Contemporary Indonesian Films". Jurnal Studi Pemuda, Vol 9 (2). doi: 10.22146/studipemudaugm.58075

Connell, Raewyn W. 2005. Masculinities. 2nd ed. Berkeley, California: University of California Press.

Crowe, Sarah, Kathrin Cresswell, Ann Robertson, Guro Huby, Anthony Avery and Aziz Sheikh. 2011. "The Case Study Approach." BMC Medical Research Methodology 11(1):100.

Ferguson, Michaele L. 2010. "Choice Feminism and the Fear of Politics." Perspectives on Politics 8 (1): 247-253.

Heaton, Tim and Mark Cammack. 2011. Explaining the Recent Upturn in Divorce in Indonesia: Developmental Idealism and the Effect of Political Change. Asian Journal of Social Science 39(6), 776. doi:https://doi. org/10.1163/156853111X619229

Heryanto, Ariel. 2011. 'Upgraded Piety and Pleasure: The New Middle Class and Islam in Indonesian Popular Culture', dalam Wientraub (ed), Islam and Popular Culture in Indonesia and Malaysia. London: Routledge. Pp. 6080.

Himawan, Karel K. 2020. "Menikah adalah Ibadah: Peran Agama dalam Merekonstruksi Pengalaman Melajang di Indonesia”. Jurnal Studi Pemuda, Vol 9 (2). doi: 10.22146/studipemudaugm.56548 
Hirshman, Linda. 2006. Get To Work: A Manifesto for Women of the World. New York: Viking.

Hull, Terence H. 2003. "Demographic Perspectives on the Future of the Indonesian Family". Journal of Population Research, 20(1), 51-66. doi:10.1007/BF03031795

Jones, Gavin W. 2005. The "Flight from Marriage" in South-East and East Asia. Journal of Comparative Family Studies, 36(1), 91-119.

Jones, Gavin W. 2007. "Delayed Marriage and Very Low Fertility in Pacific Asia". Population and Development Review, 33(3), 453-478. doi:10.1111/j.1728-4457.2007.00180.x

Jones, Gill. 2009. Youth. UK: Polity Press

Jati, Wasisto Raharjo. 2017. Politik Kelas Menengah Muslim Indonesia. Depok: LP3ES.

Koentjaraningrat. 1985. Pengantar Antropologi. Jakarta. Aksara Baru.

Kusumaningtyas, Amelinda Pandu, dan Azinuddin Ikram Hakim. 2019. "Jodoh di Ujung Jempol: Tinder Sebagai Ruang Jejaring Baru”. Jurnal Simulacra 2(2): 101-114.

Lam, Doris. 2019. "Harus Selalu Patuh Pada Orang Tua Merugikan Kesehatan Mentalku". Vice, Accessed June 25, 2020 (https://www. vice.com/id_id/article/ne $8 \mathrm{qxm} /$ harusselalu-patuh-pada-orang-tua-merugikan-kesehatan-mentalku)

McRobbie, Angela. 2004. "Post-feminism and popular culture." Feminist Media Studies 4(3): 255-264.

Minza, Marina Wenty. 2012. "Migran Muda dan Transisi dari Pendidikan ke Dunia Kerja di Pontianak, Kalimantan Barat". Jurnal Studi Pemuda 1(2): 153-164.

Nilan, Pam, Roberta Julian, and John Germov. 2007. Australian Youth: Social and Cultural Issues. Australia: Pearson Education.

Nilan, Pam 2008. "Youth transitions to urban, middle-class marriage in Indonesia: faith, family and finances". Journal of Youth Studies, 11(1): 65-82. doi:10.1080/13676260701690402
Nilan, Pam, Lyn Parker, Linda Bennett, and Kathryn Robinson,. 2011. "Indonesian Youth Looking Towards the Future". Journal of Youth Studies 14(6): 709-728.

Parker, Lyn, and Pam Nilan. 2013. Adolescents in Contemporary Indonesia. London: Routledge

Qibthiyyah, Riatu and Ariane Utomo. 2016. "Family Matters: Demographic Change and Social Spending in Indonesia". Bulletin of Indonesian Economic Studies, 52(2), 133-159. doi:10.1080/00074918.2016.1211077

Robinson, Kathryn (ed). 2015. Youth Identities and Social Transformations in Modern Indonesia: Boston: Brill.

Setiyani, Rahmi and Carol Windsor. 2019. "Filial Piety: From the Perspective of Indonesian Young Adults." Nurse Media Journal of Nursing 9 (1): 46-57.

Setyonaluri, Diahhadi, Aidah Maghfirah and Calvin Aryaputra. 2020. "Norms in Transition? The Relationship between Education and Singlehood". Jurnal Studi Pemuda, Vol 9 (2). doi:10.22146/studipemudaugm.57995

Smith-Hefner, Nancy J. 2005. "The New Muslim Romance: Changing Patterns of Courtship and Marriage among Educated Javanese Youth". Journal of Southeast Asian Studies, 36(3), 441-459. doi:10.1017/ S002246340500024X

Smith-Hefner, Nancy J. 2019. Islamizing Intimacies: Youth, Sexuality and Gender Contemporary Indonesia. USA: University of Hawai' i.

Snyder-Hall, R. Claire. 2010. "Third-Wave Feminism and the Defense of "Choice"."Women's Choices and the Future of Feminism 8 (1): 255-261. doi:10.1017/S1537592709992842.

Sutopo, Oki Rahadianto. 2013. "Hidup adalah Perjuangan: Strategi Pemuda Yogyakarta dalam Transisi dari Dunia Pendidikan ke Dunia Kerja”. Jurnal Sosiologi Masyarakat 8(2): 161-179 
Sutopo, Oki Rahadianto. 2014. "Perspektif Generasi dalam Kajian Kepemudaan" in Azca, M. Najib, Derajad S. Widhyharto, Oki Rahadianto Sutopo (Eds). Buku Panduan Studi Kepemudaan: Teori, Metodologi dan Isu-Isu Kontemporer. Yogyakarta: Youth Studies Centre Fisipol UGM.

Sutopo, Oki Rahadianto dan Nanda Harda Pratama Meiji. 2014. "Transisi Pemuda Dalam Masyarakat Risiko: Antara Aspirasi, Hambatan dan Ketidakpastian". Jurnal Universitas Paramadina 11 (3): 1164-1186.

Sutopo, Oki Rahadianto dan Nanda Harda Pratama Meiji. 2017. "Kapasitas Refleksif Pemuda dalam Transisi Menuju Dunia Kerja”. Jurnal Sosiologi Walisongo 1(1): 1-16.

Tsutsui, Junya. 2013. "The Transitional phase of mate selection in East Asian countries". International Sociology, 28(3), 257-276. doi:10.1177/0268580913484775

Utomo, Ariane. 2012. "Women as Secondary Earners: Gendered preferences on marriage and employment of university students in modern Indonesia". Asian Population Studies, 8(1), 65-85. doi:10.1080/17441730.2012.64 6841

Utomo, Ariane. 2016. "Gender in the Midst of Reforms: Attitudes to Work and Family Roles among University Students in Urban Indonesia”. Marriage \& Family Review, 52(5), 421-441. doi:10.1080/01494929.2015.1113 224

Utomo, Ariane, Anna Reimondos, Iwu Utomo, Peter McDonald, and Terence Hull. 2016. "Transition Into Marriage In Greater Jakarta: Courtship, Parental Influence, And Self-Choice Marriage". South East Asia Research 1-18. doi: 10.1177/0967828X16674134
Utomo, Ariane. 2014. "Marrying Up? Trends in Age and Education Gaps Among Married Couples in Indonesia." Journal of Family Issues 35(12):1683-1706.

Utomo, Ariane and Oki Rahadianto Sutopo. 2020. "Pemuda, Perkawinan, dan Perubahan Sosial di Indonesia”. Jurnal Studi Pemuda Vol. 9 (2).

Weintraub, Andrew. 2011. 'Introduction: The Study of Islam and Popular Culture in Indonesia and Malaysia, dalam Weintraub (ed), Islam and Popular Culture in Indonesia and Malaysia. London: Routledge. Pp. 1-16.

White, Ben. 2016. "Generation and Social Change: Indonesian Youth in Comparative Perspective". In K. Robinson (Ed.), Youth Identities and Social Transformations in Modern Indonesia (pp. 1-22): Brill.

Wolf, Diane L. 1992. Factory Daughters: Gender, Household Dynamics, and Rural Industrialization in Java. USA: University of California Press.

Wyn, Johanna and Dan Woodman. 2006. "Generation, Youth and Social Change in Australia". Journal of Youth Studies 9(5): 495-514.

Wyn, Johanna and Rob White. 1997. Rethinking Youth. Australia: Allen \&Unwin Pty Ltd 